\title{
Az életkorral arányos D-dimer-emelkedés és a SARS-CoV-2-fertőzött betegek eseti halálozása
}

\author{
Nagy Zsuzsanna ${ }^{1}$ - Vásárhelyi Barna dr. ${ }^{2}$ - Vajda Zoltán dr. ${ }^{2}$ \\ 'Semmelweis Egyetem, Általános Orvostudományi Kar Gyakorló Kórháza, Uzsoki Utcai Kórház, Budapest \\ ${ }^{2}$ Semmelweis Egyetem, Központi Laboratórium, Laboratóriumi Medicina Intézet, Budapest
}

Bevezetés: A COVID-19 kórlefolyásában újabban több szerző felvetette a D-dimer-pozitivitás és a D-dimer-emelkedés prediktív értékét a betegség súlyosbodásában, illetve az eseti halálozásban.

Célkitüzés: Magyar betegek értékeinek összehasonlítása a nemzetközi adatokkal, ennek részeként a D-dimer prediktív értéke a 2 héten belüli eseti halálozásra.

Módszerek: A szerzők 51, RT-PCR-rel igazolt SARS-CoV-2-fertőzött beteg D-dimer-eredményeit dolgozták fel retrospektív módon. Megvizsgáltuk, hogy ha a D-dimer eléri vagy meghaladja a vágóérték 4-szeresét, akkor ez milyen kockázatot (odds ratio) jelent a halálozásra. Logisztikus regresszióval meghatároztuk, hogy a 2 héten belüli halálozás esélyhányadosa a konvencionális vágóérték hányszorosa mellett lesz szignifikáns.

Eredmények: Az 51 betegből 13 halt meg a kórházba kerülést követően 2 héten belül. Megállapítottuk, hogy a tradicionális, $0,5 \mu \mathrm{g} / \mathrm{ml}$ FEU vágóérték mellett meghatározott $\mathrm{D}$-dimer-pozitivitásnak alacsony a prediktív értéke a halálozásra. Ha azt vizsgáltuk, hogy a D-dimer eléri vagy meghaladja a vágóérték 4-szeresét, és ez milyen kockázatot jelent a halálozás szempontjából, akkor a logisztikus regresszió paraméterei 1,64-szeres emelkedést mutattak ( $\mathrm{p}=0,00183$ ), és az esélyhányados (odds ratio) értéke 5,17 (CI 95\% = 1,32-20,22) volt. A D-dimer prediktív értéke a halálozásra az életkor függvényében változik. A 13 elhunyt közül 12 idősebb volt 80 évesnél, így a 80 év feletti életkor a magas D-dimer-szintnél nagyobb kockázatot jelentett a halálozásra, odds ratio: 20,7 (CI 95\% = 2,41$175,5)$.

Következtetés: A több mint négyszeres vágóértékre emelkedett D-dimer-szint az életkor mellett COVID-19-ben elöre jelezheti a 2 héten belüli halálozást.

Orv Hetil. 2020; 161(41): 1739-1743.

Kulcsszavak: D-dimer, SARS-CoV-2, RT-PCR

\section{Age-related D-dimer elevation and occasional lethality in SARS-CoV-2 infected patients}

Introduction: Recent publications have taken the idea about D-dimer as a potential marker for deadly progression of COVID-19 disease.

Objective: Evaluation of international observations involving Hungarian patients, and establishing the D-dimer level elevation as a positive predictive marker for case fatality.

Methods: Therefore these authors have elaborated the data of 51 patients positive for SARS-CoV- 2 confirmed by RT-PCR in a retrospective study. Biostatistical methods used: binary logistic regression. Evaluated parameters: medians between deaths and survivors, odds ratio calculation between deaths and survivors.

Results: Of the 51 patients 13 died within 2 weeks of hospitalization. We found that the traditional D-dimer positivity determined at a cut-off value of $0.5 \mu \mathrm{g} / \mathrm{ml} \mathrm{FEU} \mathrm{had} \mathrm{low} \mathrm{predictive} \mathrm{value} \mathrm{for} \mathrm{lethality}(0.36)$. Using the predictive value, the age-standardized D-dimer cut-off value, the odds ratio increased. When the raw concentration values were compared between the survival and non-survival group, there were sharp differences. The median value at survival was $0.65 \mu \mathrm{g} / \mathrm{ml} \mathrm{FEU}$, otherwise the concerned median at lethality was $2.21(\mathrm{p}=0.001)$. We also examined if the $\mathrm{D}$-dimer reached or exceeded 4 times the cut-off, furthermore, what the risk was for case fatality. Logistic regression 
coefficient was $1.64(\mathrm{p}=0,00183)$; odds ratio $=5.17(\mathrm{CI} 95 \%=1.32-20.22)$. Another option was to compare the age of survived and dead patients for odds of lethality. As only 1 patient died below 80 years, the authors calculated the odds of age beyond 80 for lethality. The concerned odds ratio was 20.7 (CI 95\% $=2.41-175.5$ ).

Conclusion: D-dimer marked elevation and risk for lethality seemed to be relevant. On the other hand, the collinearity between aging and D-dimer elevation is a confounding bias. It is important to consider the size of elevation of D-dimer, when the concentration is equal or greater than four times of cut-off the case lethality.

Keywords: D-dimer, SARS-CoV-2, RT-PCR

Nagy Zs, Vásárhelyi B, Vajda Z. [Age-related D-dimer elevation and occasional lethality in SARS-CoV-2 infected patients]. Orv Hetil. 2020; 161(41): 1739-1743.

(Beérkezett: 2020. július 21; elfogadva: 2020. augusztus 25.)

\section{Rövidítések}

$\mathrm{CI}=$ (confidence interval) konfidenciaintervallum; COVID-19 $=($ coronavirus disease 2019) koronavírus-betegség 2019; $\mathrm{CRP}=$ C-reaktív protein; $\mathrm{CT}=($ computed tomography $)$ számítógépes tomográfia; cut-off = vágóérték; $\mathrm{EKG}=$ elektrokardiográfia; $\mathrm{FEU}=$ (fibrinogen equivalent unit) fibrinogénekvivalens egység; $\mathrm{LMWH}=$ (low-molecular-weight heparin $)$ kis molekulatömegú heparin; odds ratio = esélyhányados; RNS = ribonukleinsav; RT-PCR $=$ (real-time polymerase chain reaction) valós idejű polimeráz-láncreakció; SARS-CoV-2 = (severe acute respiratory syndrome coronavirus 2 ) súlyos heveny légzési szindrómát okozó koronavírus-2; SOFA-score = (sequential organ failure assessment score) a szervi elégtelenség súlyossági pontrendszere; VTM = vírustranszport-médium; $\mathrm{WHO}=$ (World Health Organization) Egészségügyi Világszervezet

Először Huang és mtsai közölték, hogy a D-dimer-referenciatartomány felső határának a négyszeresét is meghaladó érték volt azokban a COVID-19-fertőzött betegekben, akik később meghaltak, míg az alacsony D-dimer-szint mellett a túlélési arány magasabb volt [1]. Bár később más szerzők ennyire markáns különbséget nem találtak, hangsúlyozták, hogy a vágóérték feletti eredmény $(>0,5 \mu \mathrm{g} / \mathrm{ml}$ FEU) és a halálozás összefügg [2-4].

Ennek következtében a preventív antikoaguláció fontosságát ma már több szerző hangsúlyozza. Javasolják az alacsony molekulatömegü heparin (LMWH) profilaktikus dózisban való mérlegelését, ha a betegnek jelentősen emelkedett D-dimer-szintje van. Ennek okai az intenzív gyulladás, a hypoxia, az immobilizáció, melyek stimulálják a tüdőben a belső fibrinolysist. Ezeknél a betegeknél a vénás thromboembolia fokozott kockázata áll fenn. Megállapították, hogy az LMWH-val történő kiegészítő kezelés jelentősen csökkenti a halálozási kockázatot [5, 6]. Újabban magyar szerzők eredményei is támogatják a terápiás alvadásgátló kezelés és a thrombocytaaggregáció-gátlás fontosságát [7].

Ezek a közlések több kórélettani kérdést is felvetnek. Az régóta elfogadott, hogy a D-dimer akutfázis-reaktáns, nem specifikus módon emelkedik gyulladásokban. Az is ismert, hogy a COVID-19 patogenezisében a gyulladásnak és az ún. „citokinviharnak” komoly szerepe van a kórfolyamat súlyosbodásában [8,9]. Mivel a gyulladás és a fibrinolysis molekuláris szinten több ponton is kapcsolódik egymással, a D-dimer-emelkedés a COVID-19infekcióban akár ezzel is magyarázható lehet $[2,8]$. A D-dimer-szint ráadásul még egészségesekben is emelkedik az életkorral [10, 11]. Az, hogy az időskor a COVID-19-halálozásban független rizikófaktor, Graziano Onder munkája óta ismert és elfogadott [12].

Retrospektív vizsgálatot végeztünk magyar betegeken a D-dimer-szint prediktív értékének meghatározása céljából a COVID-19-ben 2 héten belül bekövetkező halálozásban. Az egyébként már fellelhető nemzetközi adatokkal összehasonlítottuk a sajátjainkat, mivel ismert a betegség regionális különbözősége.

\section{Betegek és módszerek}

Retrospektív módon dolgoztuk fel 51, az Uzsoki Utcai Kórházban 2020. március-április hónapban kezelt beteg adatait. Azok a betegek kerültek beválasztásra, akiknél D-dimer-vizsgálat megtörtént, tekintettel arra, hogy a kórházi COVID-protokollban a D-dimer-vizsgálat, mint rutin, nem volt elöírva. Az adatok összegyưjtése során figyelembe vettük a betegek korát, D-dimer-eredményét és a kórházba kerüléstől számított halálozást. További adatgyüjtéssel a betegek nemét és a társbetegségeket vizsgáltuk (pneumonia, hypertonia, diabetes, atherosclerosis, stroke stb.). A COVID-19 diagnózisát a WHO iránymutatása alapján határoztuk meg [13].

Az RT-PCR-vizsgálathoz a naso- és oropharyngealis minta a megfelelő vírustranszport-médiumban (VTM) került a mikrobiológiai laboratóriumba, $4-6{ }^{\circ} \mathrm{C}$-on szállítva, 24 órán belül. A vírus-RNS kivonása MagNa Pure 96 nukleinsav-izoláló készüléken, a vírusamplifikáció és -detektálás (SARS-CoV-2 E-gene, SARS-CoV-2 RdRP gene) LightCycler 480 készüléken (Roche, Bázel, Svájc) történt. A szükséges reagensek CE-IVD minősítésúek voltak. A betegek D-dimer-értékét a kórházba kerülést követően határozta meg a laboratórium. A D-dimer la- 
1. táblázat $\mid$ A logisztikus regresszió eredménye

\begin{tabular}{|c|c|c|c|c|c|c|}
\hline Független/függő változó & Regressziós koefficiens & $\mathrm{p}$ & Konstans & $\mathrm{p}$ & OR & $95 \% \mathrm{CI}$ \\
\hline D-dimer-pozitív/letalitás & 0,36 & $<0,0179$ & $-1,81$ & 0,002 & 1,05 & $1,05-1,19$ \\
\hline Életkor-specifikus pozitivitás/letalitás & 1,02 & 0,1349 & $-1,66$ & 0,000 & 2,78 & $0,72-10,62$ \\
\hline Életkor>80 év/letalitás & 3,02 & 0,002 & $-3,18$ & 0,006 & 20,57 & $2,41-175,52$ \\
\hline 4-szeres emelkedés/letalitás & 1,65 & 0,0183 & $-1,64$ & 0,0002 & 5,17 & $1,32-20,22$ \\
\hline
\end{tabular}

$\mathrm{CI}$ = konfidenciaintervallum; OR = esélyhányados

tex immunoesszé a Diagon Kft. gyártmánya, a mérés a Diagon CoagXL koagulométerén történt. Megvizsgáltuk, ha a D-dimer eléri vagy meghaladja a vágóérték 4-szeresét, akkor ez milyen kockázatot jelent az eseti letalitás szempontjából. Logisztikus regresszióval meghatároztuk, hogy a 2 héten belüli letalitás esélyhányadosa a konvencionális vágóérték hányszorosa mellett lesz szignifikáns.

\section{Statisztikai analízis}

A D-dimer és a halálozás összefüggésének elemzéséhez több megközelítést használtunk. Az első számításban a D-dimer-pozitivitást az általánosan használt vágóérték $(0,5 \mu \mathrm{g} / \mathrm{ml}$ fibrinogénekvivalens egység [FEU]) mellett vizsgáltuk. A második megközelítésben a vágóértéket Douma módszere szerint számoltuk, vagyis a vágóérték $\mu \mathrm{g} / \mathrm{ml}$ FEU egyenlő az életkor években, szorozva 0,01gyel [10]. Vizsgáltuk azt is, hogy önmagában az életkor előrehaladása dekádonként mennyire növeli a halálozást. Az adathalmazokat a mediánjukkal, az ahhoz tartozó 95\%-os konfidenciaintervallumukkal és a maximum-minimum értékekkel jellemeztük. Annak meghatározására, hogy a D-dimer és a 2 héten belüli halálozás között van-e korreláció, vizsgáltuk a D-dimer-pozitivitás jósló értékét, illetve bináris logisztikus regressziót is végeztünk. A 2 héten belül meghaltak és a túlélők D-dimer-koncentrációja közötti összefüggést Mann-Whitney-teszttel vizsgáltuk.

\section{Eredmények}

A vizsgált 51 beteg 41\%-a férfi, 59\%-a nő volt. Az 51 betegből 13 halt meg a felvételt követő 2 héten belül. Ebből 12-en voltak a 80 . életéven túl, 1 volt 70 és 80 éves kor között. A csoport életkori mediánja 80 év volt (tartomány: 30-93 éves korig). A túlélők átlagéletkora 71 év volt, közülük 4 tüdőemboliás volt. Ezt a klinikai kép alapján, illetve CT-vel (tüdőangiográfia), EKG-val, Astrup- és D-dimer-vizsgálattal igazolták. Mélyvénás thrombosisa 1 betegnek volt, melyet a Wells-score alapján diagnosztizáltak.

Az 51 betegnél a D-dimer-szint mediánja 0,90 (0,138,19) $\mu \mathrm{g} / \mathrm{ml} \mathrm{FEU} \mathrm{volt.}$

Amennyiben a D-dimer-pozitivitást használtuk (a konvencionális vágóérték alapján definiálva), majd a ha- lálozást ennek függvényében néztük, akkor a logisztikus regresszió egyenlete a következőnek bizonyult:

- odds ratio: 1,05 (95\% CI = 1,05-1,19).

Amennyiben nem a szokványos, hanem az életkorra illesztett vágóérték alapján végeztük el a fenti analízist, akkor a D-dimer-pozitivitás és a halálozás közötti összefüggés a következőképp alakul:

- odds ratio: $2,78(95 \% \mathrm{CI}=0,72-10,62)$.

Ha a betegeket életkori dekádokba soroltuk (30-39, 40-49, 50-59, 60-69, 70-79 és 80 éven túl), akkor a 80 éves kor feletti életkor és a halálozás közötti összefüggés logisztikus regresszióval:

- odds ratio: 20,57 (CI 95\% = 2,4-175,52).

Ha a betegeket két csoportra osztjuk (vagyis az elhaltakra és a túlélőkre), akkor viszont markáns különbséget találunk a D-dimer-koncentrációkban:

- a túlélők D-dimer-koncentrációjának mediánja 0,65 $(0,13-7,27) \mu \mathrm{g} / \mathrm{ml} \mathrm{FEU}$ volt,

- míg az elhaltaknál ez az érték 2,21 $(0,45-8,19)$ ug/ ml FEU volt.

Kimutattuk, hogy ha a D-dimer-emelkedés eléri vagy meghaladja a konvencionális vágóérték $(0,5 \mu \mathrm{g} / \mathrm{ml}$ FEU) négyszeresét, az eseti halálozás esélyhányadosa 5,17 lesz (1,32-20,22). A logisztikus regresszió koefficiense $1,64(\mathrm{p}=0,0002)$ volt (1. táblázat).

A Mann-Whitney-teszt eredménye $\mathrm{p}=0,0068$ volt (2. táblázat).

Elvégeztük az életkor szerinti vágóértékek kiszámolását (életkor $\times 0,01)$. Az így elvégzett kockázatbecslés, azaz a vágóérték feletti $\mathrm{D}$-dimer-koncentráció eredménye negatív volt.

A kísérő betegségek statisztikájában vezető szerepet tölt be a hypertonia, a diabetes, az ischaemiás szívbetegségek, illetve az egyéb szíveredetû megbetegedések. Az esetek nagy százalékában ezekkel az akut diagnózisokkal kezelték a kórházba került betegeket, a COVID-19 mel-

2. táblázat A 2 héten belül elhunyt és a túlélő betegek D-dimer-értékeinek összehasonlítása

\begin{tabular}{lc|c}
\hline & Túlélő & Elhunyt \\
\hline Minimum & 0,13 & 0,45 \\
Maximum & 7,27 & 8,19 \\
25-75\% percentilis & $0,36-1,15$ & $0,91-3,99$ \\
Mann-Whitney-teszt & \multicolumn{2}{c}{0,0068} \\
\hline
\end{tabular}


3. táblázat |A kísérő betegségek statisztikája

\begin{tabular}{lr}
\hline Komorbiditás & $65 \%$ \\
\hline Hypertonia & $31 \%$ \\
Diabetes & $31 \%$ \\
Ischaemiás szívbetegség és egyéb szíveredetű betegségek & $27 \%$ \\
Pneumonia & $23 \%$ \\
Krónikus obstruktív tüdóbetegség, légzési elégtelenség, & \\
tuberculosis & $16 \%$ \\
Atherosclerosis & $16 \%$ \\
Vesebetegségek & $0,7 \%$ \\
Tüdőembolia & $0,06 \%$ \\
Mélyvénás thrombosis, stroke & $0,06 \%$ \\
Rosszindulatú daganat & $0,02 \%$ \\
Septicaemia & $16 \%$ \\
Egyéb társbetegség & \\
\hline
\end{tabular}

lett (3. táblázat). Egyetlen esetben diagnosztizáltak septicaemiát (a beteg meghalt). Mivel a beteg állapota nem indokolta az intenzív osztályos kezelést, SOFA-scoreszámolás nem történt. Ebben az időszakban a boncolások mellőzése miatt a szervi szövődményekre vonatkozó információkra nem tudtunk adatokat gyújteni.

\section{Következtetés}

Eredményeink azt mutatják, hogy COVID-19 súlyos eseteiben a D-dimer-szint prediktív lehet az eseti halálozásra, Huang első közlésével összhangban [1]. Igazoltuk, hogy a vágóérték négyszeres növekedése az eseti halálozás szignifikáns növekedését jelenti.

Árnyalja a képet, hogy az idős életkor is független rizikófaktor a COVID-19-halálozásban. 80 éves kor felett az eseti halálozás esélyhányadosa 20,57. Ez az esélyhányados jóval magasabb, mint a D-dimer és az életkor összefüggésében talált érték $(1,63)$.

Ez rávilágít arra, hogy a $\mathrm{D}$-dimer prediktív értéke a halálozásban az életkortól függetlenül nehezen értelmezhető. A Douma által javasolt, életkor-specifikus referenciaérték itt nem volt informatív, ami azzal magyarázható, hogy Douma azt kifejezetten a mélyvénás thrombosis diagnosztikai értékének javítására dolgozta ki.

Érdemesnek látszik megjegyezni, hogy ha a vágóértéket Douma szerint az életkor függvényében diverzifikáljuk, azaz nem egységesen a 0,5-ös értéket használjuk a koefficiens letalitás logitjára, akkor az a tradicionális vágóértékhez képest jelentősen emelkedik (1,02 vs. 0,36) az odds ratio emelkedése mellett (mindkét érték szignifikáns).

Adataink jó egyezést mutatnak Lippi és Favaloro [14] metaanalízisen alapuló, részletes összefoglalójával, amelyben a D-dimer-emelkedés és a folyamatában sú- lyossága közötti szorzó faktor a 2-től egészen a 8-szorosig terjedt.

Retrospektív adatelemzésünk sajnos nem ad arra lehetőséget, hogy a D-dimer-emelkedés mint jelenség hátterében mi az önálló szerepe a SARS-CoV-2-infekciónak, illetve az öregedésnek. Ilyen mintaszám alapján ez nem is lehetett célunk. További korlát az, hogy nem tudjuk, a 2 hét után/belül hazabocsátott betegek között az ezt követő időszakban mekkora a rövid távú halálozás.

Anyagi támogatás: A közlemény megírása anyagi támogatásban nem részesült.

Szerzôi munkamegosztás: N. Zs.: Vizsgálatok végzése, a vizsgálati eredmények összegyưjtése, a közlemény kijavítása. V. Z.: Adatelemzés, a közlemény megírása, klinikai következtetések. V. B.: A közlemény kijavítása, klinikai következtetések. A cikk végleges változatát valamennyi szerző elolvasta és jóváhagyta.

Érdekeltségek: Dr. Vajda Zoltán a Diagon Kft. külső szakmai tanácsadója. A további szerzőknek nincsenek érdekeltségeik.

\section{Irodalom}

[1] Huang C, Wang Y, Li X, et al. Clinical features of patients infected with 2019 novel coronavirus in Wuhan, China. Lancet 2020; 395: 497-506. [Correction: Lancet 2020 Jan 30.]

[2] Kollias A, Kyriakoulis KG, Dimakakos E, et al. Thromboembolic risk and anticoagulant therapy in COVID-19 patients: emerging evidence and call for action. Br J Haematol. 2020; 189: 846847.

[3] Tang N, Li D, Wang X, et al. Abnormal coagulation parameters are associated with poor prognosis in patients with novel coronavirus pneumonia. J Thromb Haemost. 2020; 18: 844-847.

[4] Wang D, Hu B, Hu, C, et al. Clinical characteristics of 138 hospitalized patients with 2019 novel coronavirus-infected pneumonia in Wuhan, China. JAMA 2020; 323: 1061-1069.

[5] Thachil J. The versatile heparin in COVID-19. J Thromb Haemost. 2020; 18: 1020-1022.

[6] Klok FA, Kruip MJ, van der Meer NJ, et al. Incidence of thrombotic complications in critically ill ICU patients with COVID-19. Thromb Res. 2020; 191: 145-147.

[7] Zátroch I, Smudla A, Babik B, et al. Procoagulation, hypercoagulation and fibrinolytic "shut down" detected with ClotPro ${ }^{\circledR}$ viscoelastic tests in COVID-19 patiens. [Procoagulatio, hypercoagulatio és fibrinolysis „shut down” kimutatása ClotPro ${ }^{\circledast}$ viszkoelasztikus tesztek segítségével COVID-19-betegekben.] Orv Hetil. 2020; 161: 899-907. [Hungarian]

[8] Dolhnikoff M, Duarte-Neto AN, de Almeida Monteiro RA, et al. Pathological evidence of pulmonary thrombotic phenomena in severe COVID-19. J Thromb Haemost. 2020; 18: 15171519.

[9] Mehta P, McAuley DF, Brown M, et al. COVID-19: consider cytokine storm syndromes and immunosuppression. Lancet 2020; 395: 1033-1034.

[10] Farm M, Siddiqui AJ, Onelöv L, et al. Age-adjusted D-dimer cut-off leads to more efficient diagnosis of venous thromboembolism in the emergency department: a comparison of four assays. J Thromb Haemost. 2018; 16: 866-875. 
[11] Schouten HJ, Koek HL, Oudega R, et al. Validation of two age dependent D-dimer cut-off values for exclusion of deep vein thrombosis in suspected elderly patients in primary care: retrospective, cross sectional, diagnostic analysis. BMJ 2012; 344: e2985.

[12] Onder G, Rezza G, Brusaferro S. Case-fatality rate and characteristics of patients dying in relation to COVID-19 in Italy. JAMA 2020; 323: 1775-1776.

[13] Akl EA, Blazic I, Yaacoub S, et al. Use of chest imaging in the diagnosis and management of COVID-19: a WHO rapid advice guide. [Published online ahead of print 2020 Jul 30.] Radiology $2020 ; 203173$

[14] Lippi G, Favaloro EJ. D-dimer is associated with severity of coronavirus disease 2019: a pooled analysis. J Thromb Haemost. 2020; 120: 876-878.

(Nagy Zsuzsanna,

Budapest, Uzsoki utca 29-41., 1145 e-mail: nagy.zsuzsanna@uzsoki.hu)

\section{"Securus mortuus est, qui scit in morte renasci." (Boldogan hal meg, ki remél új életet.)}

A cikk a Creative Commons Attribution 4.0 International License (https://creativecommons.org/licenses/by/4.0/) feltételei szerint publikált Open Access közlemény, melynek szellemében a cikk bármilyen médiumban szabadon felhasználható, megosztható és újraközölhetö, feltéve, hogy az eredeti szerzỏ és a közlés helye, illetve a CC License linkje és az esetlegesen végrehajtott módosítások feltüntetésre kerülnek. (SID_1) 